\title{
Research on Contemporary Significance of Marx's Political Socialization
}

\author{
Chuanhao Ma \\ Student affairs office of Nanjing Xiaozhuang University Jiangsu Province Nanjing City211171
}

\author{
Keywords: Marxism, Philosophical Thought, Contemporary Significance
}

\begin{abstract}
From the political point of Marxist philosophy to confirm the political philosophy of the provisions of the political philosophy of its focus on practical reality, learn from the essence of traditional Chinese political philosophy, contemporary Chinese political philosophy is of great significance. Through the study of Marx's research on economic problems and the philosophical thinking on some basic economic problems, this article explores the connotation of Marx's economic philosophy, and on this basis, expounds the important significance of Marx's economic philosophy in contemporary times. Marx's thought has the core position in Marx's theory, and runs through all the theories of Marx's philosophy, political economy and scientific socialism. In the contemporary era, Marx's humanistic thought has extremely important theoretical and practical significance, and this idea and its theoretical achievements in contemporary China should be used as the guiding ideology of building socialism with Chinese characteristics.
\end{abstract}

\section{Theoretical Introduction of Marx's political}

Marx's political thought was formed on the basis of absorbing the ideological resources of Western political ethics and criticizing the political and economic reality of Western capitalism. Marx's political ethics thought is based on the "real person", taking human liberation as the ultimate goal, taking historical materialism as the basis and method, while criticizing the capitalist society and feudal society unethical while trying to build a fair and just a human society. Our grasp of the basic viewpoints of Marx's political ethics can be understood from three dimensions: the political nature of Marx's philosophy, the critique of political economy, and the method of scientific socialism. Marx's political ethics thought transcends the western political ethic tradition, which transcends essentially a way of thinking of practical materialism, with critical and constructive interaction, from the perspective of philosophy or ethics to grasp the political, but also from the political to understand philosophy or ethics.

In terms of political relations, political relations are essentially the manifestations of the real social relations of "real people", which refers to the relationship between the individual and the state, the political relationship that revolves around the relationship between power and rights. Human social relations and political relations are essentially alienated, completely contrary to the nature of the people and the integration of individuals and society. The essence of human beings is the real social connection of people, so people in the process of actively realizing their own nature to create, produce people's social connections and essence ${ }^{[1]}$.

Although Marx is constructing his political ethic thought in criticizing the old capitalist society, his criticism of the alienation of capitalism, the practice of materialistic way of thinking and the value of human liberation are still indispensable for the construction of contemporary political ethics. Marx's political ethics thought for the construction of contemporary Chinese political ethics theory, promote the development of socialism with Chinese characteristics, political civilization still has a very important theoretical value and practical significance. 


\section{Realistic Significance of Marx's Political Socialization}

The basic principles of Marxism laid the theoretical foundation for the political socialization of our citizens. Many scholars have explored the theory of the relationship between social existence and social consciousness, the relationship between politics and economy, economic foundation and superstructure, from the perspective of Marxist theory of socialization of Chinese citizens. Ideological and political education guide people to establish a correct world outlook of life and values, so as to lay the foundation for the whole development. Through the ideological and political education of political socialization process, so that people get the correct political awareness, the formation of political value evaluation, to develop a good political psychology, firm political beliefs, improve political awareness and level, to promote the individual's own quality and enhance ${ }^{[2]}$.

Socialism with Chinese characteristics is the great historical creation that our party has continued to promote the localization of Marxism in China since the new period. The world is undergoing extensive and profound changes in the world, and some of the shortcomings of the new situation and the traditional ideological and political education are increasingly exposed, which requires the transformation of the traditional concept of ideological and political education, and actively explore new ways and new methods. Ideological and Political Education Playing the Value of Political Socialization is the Inevitable Result of the Socialization and Life - oriented Trend of Ideological and Political Education. It is in the community of various forces and the main body to participate in the promotion of the whole people to develop the system engineering, but also the process of continuous transformation and development of society.

At the same time, ideological and political education was from social life, with continuous development and improvement in the social life. Ideological and political education to play a political social value, is conducive to the government to keep abreast of public opinion and public opinion, and widely for the people's views, can promote better improvement, the implementation of party and government policies to improve the party and government governance level and scientific; Which is conducive to the supervision of the government's management behavior, thereby inhibiting the proliferation of corruption, to improve the party and government staff ideological and moral standards and political consciousness, and establish the public service of the people wholeheartedly, and always maintain the party's advanced nature, The implementation of government affairs, so that power in the sun exercise ${ }^{[3]}$.

\section{Contemporary Significance of Marx's Political Socialization}

Marx's political thought to absorb contemporary Western economic theory to provide ideas to guide the Marxist philosophy of the economy has a critical and revolutionary nature, it still has immeasurable value, it is for us to critically absorb the contemporary Western economic theory provides a very important Ideological guidance. From the historical and the overall point of view, the contemporary significance of Marx's political socialization is multifaceted. This article mainly deals with the following three aspects.

In order to construct a new and complete theoretical system of political economy, Marx provides methodological guidance to construct from abstract to concrete scientific methods and some important methodological principles, which are important for us to construct a new and complete theoretical system of political economy guiding significance. On the basis of the new understanding of the unity of socialism and market economy under the conditions of the socialist market economy, to reconstruct the new and complete theoretical system of political economy, then, from the abstract to the concrete science methods, the rationale about the logical starting point of the theoretical system, the idea of the economic category order, etc., are the principles that we should follow and follow. Marx's philosophy of economic philosophy is the basic basis for the correct understanding of the root causes of contemporary economic globalization on the idea of taking historical materialism as a guide to economic research ${ }^{[4]}$. Fig. 1 shows contemporary significance of Marx's political socialization. 


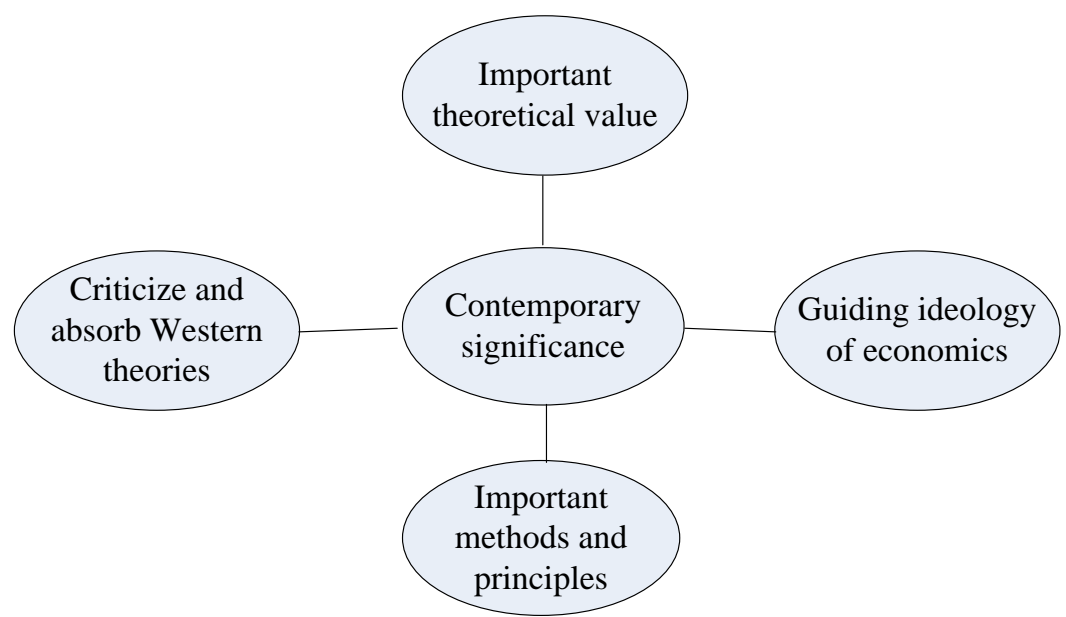

Fig. 1.The contemporary significance of Marx's political socialization

Marx's political ethical thought is of great theoretical value in constructing contemporary Chinese political theory. The theory of historical materialism on social basic contradictions holds that the ultimate driving force of social development lies in productivity, and the reaction of productive relations to productive forces determines the nature and development trend of social form. Marxist political ethics through the analysis of philosophy and the use of historical materialism theory and method, profoundly reveals the political relationship from "should" to "real" the correct way to change, that is, to establish a fair and just society of human society, to promote The free and all - round development of human beings indicates the direction of future social development. Obviously, Marx's political ethics is the guide and method of constructing contemporary Chinese political ethics. We should use this as the basis to criticize and absorb the traditional thoughts of Chinese and western political ethics and Marx's political and ethical traditions after Marxism.

\section{Contemporary Significance of Marxist Political Education}

From the perspective of cultivating qualified social and political individuals, the functions of Marxist political science in our country's political education are as follows: college students are in the political view, state view and political values consistent with the socialism with Chinese characteristics. The formation of the basic political principles of Marxist political science education and political values preach in guiding the basic political views of young college students can play an important role. To play the positive role of Marxist political science in the process of political socialization, the first is to play a good Marxist political science in the university political education in the important role, and play a good Marxist political science in the university political education in the important role must live course and discourse two basic links ${ }^{[5]}$.

Marxist political science can explain the political science in detail and introduce the basic common sense of political life, compare the advantages and disadvantages of different political systems, cultivate the political discrimination ability and political criticism ability of the individual, expose some seemingly popular politics The interest behind the language, revealing the political nature hidden in the complex social relations, correctly understanding the political interests and social interests of the joint relationship, to improve the individual social participation in political initiative, consciousness, cultivate social individual political participation in the basic ability and skills The Marxist political science is particularly good at political social analysis, and focuses on the analysis of the situation of Chinese society, critically analyzed the political nature of Western society, in the effective provision of socialism with Chinese characteristics, political basic political knowledge and improve the corresponding political Participation in the ability to have a clear academic advantage.

Marxist political science in the context of China has gained an important stage of development, its objective situation of Chinese politics has a very deep study, not only can be a detailed 
introduction to the various aspects of China's political system, the introduction of Chinese society special political The benefits of channel and political information communication, but also can provide local political participation in different situations of detailed knowledge, to introduce different social classes affect the political decision-making approach, media and influence, etc., can also introduce China's political decision-making system, procedures and impact elements, etc., provide political participation necessary for policy interpretation of education. The close relationship between the individual members of the modern society and the community is mainly through politics. In a sense, the social individual has benefited from the community's political decision-making, which has become a necessary parameter for the consolidation of the political community.

\section{Conclusions}

In today's era, Marx's political philosophy should keep pace with the times, and the subject of concern should also change with the theme of the times. Marx's philosophy of economic philosophy mainly includes: the establishment of historical materialism as the guiding ideology of economic research; the use of materialist dialectics on the analysis of basic economic issues; establish from the abstract to the specific method for the construction of economic theory system of scientific methods. The political development path of socialism with Chinese characteristics requires consciously play the influence of Marxist political discourse, intensify the breadth, depth and intensity of Marxist political science in discourse influence, guide the process of political socialization of college students and effectively resist the adverse effects of Western political discourse, training with the Chinese characteristics of the socialist political development path to adapt to the young political people. Marx's philosophy of economic philosophy has important guiding significance for critically absorbing contemporary western economic theory and constructing a new and complete theoretical system of Marxist political economy.

\section{References}

[1] William Ebenstein, Alan Ebenstein. Great Po1itical Thinkers: Plato to the Present [M]. BerLin: Harcourt College Publishers, 2003.

[2] K Sandra Nadclson. The Role of the Environment in Student Ethical Behavior. USA: Journal of College \& Character, 2006.

[3] Hu Liqun. Understanding and error corrections of the ideological and political life of education [J]. Science Education, 2008 (4): 76-77.

[4] An Qilian. A Study of Marxist Philosophy in China [M]. Beijing: China Renmin University Press. 2006.

[5] Yu Wujin. Masked Marx [M]. Beijing: People's Publishing House. 2012. 